\title{
Hepatorenal Protective Activities of Plantain Root (Musa paradisiaca) on Arsenic-induced Oxidative Damage in Rat
}

\author{
Oluwole Israel Oyewole ${ }^{1, *}$, Tolulope Olufunmilayo Akinbamijo ${ }^{2}$, Oluwabukola Joy Omoboriowo ${ }^{1}$, \\ Naomi Ubongabasi Ukana ${ }^{1}$
}

${ }^{1}$ Department of Biochemistry, Osun State University, Osogbo, Nigeria

${ }^{2}$ Department of Biochemistry, Federal University of Technology, Akure, Nigeria

\author{
Email address: \\ ioluoye@yahoo.com (O. I. Oyewole)
}

\section{To cite this article:}

Oluwole Israel Oyewole, Tolulope Olufunmilayo Akinbamijo, Oluwabukola Joy Omoboriowo, Naomi Ubongabasi Ukana. Hepatorenal Protective Activities of Plantain Root (Musa paradisiaca) on Arsenic-induced Oxidative Damage in Rat. Advances in Biochemistry. Vol. 3, No. 2, 2015, pp. 30-34. doi: 10.11648/j.ab.20150302.12

\begin{abstract}
The protective role of aqueous root extract of Musa paradisiaca on arsenic chloride-induced oxidative damage in the liver and kidney of albino rats was investigated in this study. Twenty four albino rats were grouped in to four (A, B, C and D). Group A served as the control and received distilled water while B, C and D were administered $10 \mathrm{mg} / \mathrm{kg}$ bw of arsenic chloride weekly. Groups C and D were treated with 200 and $500 \mathrm{mg} / \mathrm{kg}$ bw of aqueous extract of Musa paradisiaca roots respectively for 28 days while group B was left untreated. Phytochemical screening carried out on the root powder indicated the presence of tannins, terpenoids, steroids, sarponins, cardiac glycosides and flavonoids. Arsenic chloride induced a significant elevation in aminotransferases (ALT and AST), ALP and total bilirubin and reduction in serum protein and albumin indicating derangement of liver function. Significant elevation of serum creatinine, urea, uric acid, blood urea nitrogen and electrolytes levels were also recorded in arsenic intoxicated rats indicating disruption of kidney function. Histological examination of the kidney and liver of arsenic intoxicated rats also indicated significant alteration in tissue architecture and morphology. There was significant increase in the liver and kidney weight index in arsenic treated groups compared to the control indicating tissue inflammation. Treatment of rats with different doses of Musa paradisiaca root extract significantly $(\mathrm{P}<0.05)$ normalized liver and kidney functions while it also restored normal tissue histology at the end of the experiment. It can be concluded that Musa paradisiaca contain bioactive constituents capable of protecting the living system against arsenic-induced disruption of liver and kidney functions in rats.
\end{abstract}

Keywords: Musa paradisiaca, Arsenic Chloride, Liver Function, Kidney Function

\section{Introduction}

The liver and the kidney are vital organs which perform many important metabolic and regulatory functions and are responsible for maintaining homeostasis of the body. Epidemiological studies all over the world indicates a rapidly growing morbidity and mortality from liver and kidney diseases attributable to increasing number of chemical compounds and environmental pollution [1]. A number of chemical agents which are used on routine basis or injected through pollution has been found to produce oxidative cellular damage to the liver and kidney [2].

Arsenic is a ubiquitous element in the environment which enters the food chain through dissolution in rain, rivers or groundwater, industrial wastes discharge, fertilizers, pesticides and burnings of fossil fuels [3]. Daily human intake of arsenic contained in food ranges from $0.5-1.0 \mathrm{mg}$, with the greatest concentrations coming from fish and crustaceans [4]. Arsenic represents a potential threat to the environment, human and animal health due to their oxidative effects. It cause elevated production of hydrogen peroxide which might form reactive oxygen species and oxidative stress [5].

Arsenic and its compounds disrupt ATP production by inhibiting pyruvate dehydrogenase and succinate dehydrogenase in the citric acid cycle. It also impair cell respiration by competing with phosphate and uncouples oxidative phosphorylation [6]. 
Several medicinal plants have been investigated to be useful in the treatment of wide variety of liver and kidney disorders. These plants were examined to possess antioxidant properties which play important role in inhibiting and scavenging free radicals and thus providing protection against infections and degenerative disorders [7]. Plantain (Musa parasidiaca) is a herbaceous perennial herbs growing in almost all regions of the world including Africa. The roots are medicinally used as an antibacterial, antidote and antiseptic agent [8]. Decoction of the roots is used in the treatment of a wide range of complaints including diarrhea. Plantain root contain aucubin (a glycoside) and apigenin (a flavonoid) which have been widely studied for their numerous effects in inflammation [9]. The present study was designed to evaluate the possible ameliorative potential of Musa paradisiaca root extract on arsenic induced liver and kidney toxicity in rats.

\section{Materials and Methods}

Arsenic chloride used is a product of Burgoyne Burbidges and Co, Mumbai, India. Protein, albumin, ALP, ALT, AST, bilirubin, creatinine, uric acid, urea and chloride kits were all products of Randox Laboratories Limited, United Kingdom. All other chemicals were obtained in analytical grade and were prepared using distilled water.

\subsection{Collection of Plantain Roots and Phytochemical Screening}

Plantain root (Musa paradisiaca) was harvested from a farm in Osogbo town, Osun state, Nigeria. It was peeled washed and cut into tiny pieces. The roots were air-dried for six (6) weeks and then ground into powder using a Binatone 1200QX electric blender. They were stored in an air- tight polythene bag until use. Phytochemical screening on the root powder was carried our using standard method [10].

\subsection{Preparation of Extract}

$500 \mathrm{~g}$ of the powdery roots of Musa paradisiaca was soaked in 3.0 litres of distilled water for 10days at room temperature. The mixture was filtered using a moslin cloth. The extract was then concentrated using rotary evaporator at $100^{\circ} \mathrm{C}$. The thick pasty dark brown residue obtained was weighed and refrigerated until required.

\subsection{Management of Experimental Animals}

Twenty four (24) male albino rats (average weight $150 \mathrm{~g}$ ) sorted into four groups were obtained from the Central Animal House, Osun State University, Osogbo Nigeria. Group A serves as the control and administered distilled water. Group B, C and D were administered $10 \mathrm{mg} / \mathrm{kg}$ bw of arsenic chloride weekly. Group C and D were treated with $200 \mathrm{mg} / \mathrm{kg}$ bw and $500 \mathrm{mg} / \mathrm{kg}$ bw of the extract respectively for 28 days while group B were left untreated. The rats were housed in well ventilated plastic cages and kept under laboratory condition of optimum temperature and relative humidity. The cages were cleaned twice daily. Rats were allowed to acclimatize for 2 weeks before the drug administration began. They were exposed to $12 \mathrm{hrs}$ daylight and 12 hrs darkness and were fed rat pellets and water ad libitum. The extracts were dissolved in distilled water and administered to the rats daily with the aid of oral canula.

\subsection{Collection of Blood Samples}

Rats were sacrificed by hitting the head against hard objet. The jugular vein was cut and blood collected immediately into plain bottles and allowed to clot. It was then centrifuged at $3000 \mathrm{rpm}$ for $30 \mathrm{mins}$ after which it was refrigerated.

\subsection{Histological Procedure}

Histological examination was done using the method described by Bancroft and Stevens [11]. A fine section of the tissues (liver and kidney) were cut with a clean, sterile scissors and immediately transferred into $10 \%(\mathrm{v} / \mathrm{v})$ formaldehyde saline solution. 7-10 mm semi-serial cuts slice tissues were dehydrated through ascending grades of ethanol (70\%, 90\% and $95 \% \mathrm{v} / \mathrm{v})$, cleaned in xylene and embedded in paraffin wax. They were stained with haematoxylin and eosin, mounted in a Leitz microscope and their photomicrograph taken at X 400 with a Canon (Meville, NY) Power Shot G2 Digital Camera.

\subsection{Biochemical Analysis}

Total protein concentration was estimated using Biuret method [12]. Albumin concentration was determined based on its quantitative binding to bromo cresol green to form albumin-BCG complex [13]. Serum levels of AST and ALT were determined by the methods of Reitman and Frankel [14]. ALP activity was determined by the method of Wright et al. [15] based on its ability to hydrolyse p-nitrophenylphosphate to give phosphate and p-nitrophenol. Total bilirubin determination was based on the principle described by Jendrassik and Grof [16]. Serum urea concentration was determined based on Berchelot's reaction [17]. Serum uric acid was estimated using the photometric method described by Fischbach and Dunning [18]. Serum creatinine (using Jaffe reaction), bicarbonates and chloride ion were determined as described by Tietz et al. [19]. Blood urea nitrogen (BUN) was calculated using appropriate formula. Serum $\mathrm{Na}^{+}$and $\mathrm{K}^{+}$were determined by flame photometry using Jenway P7 flame photometer. The absorbances of all the samples were measured using spectrophotometer (HAICH, DR 3000, Germany).

\subsection{Statistical Analysis}

Data obtained were subjected to statistical analysis with the use of standard student's t-test method. $\mathrm{P}<0.05$ were regarded as significant. The group data were expressed as mean $\pm \mathrm{SD}$.

\section{Results}

Phytochemical screening carried out on Musa 
paradisiacal root reveal the presence of tannins, terpenoids, steroids, sarponins, cardiac glycosides and flavonoids.

The results of kidney and liver body weight index is shown in Table 1. Rats administered arsenic (Group B) recorded significant increase in liver and kidney weight compared to the control while there was no significant difference in the kidney and liver body weight index of rats treated with Musa paradisiaca root extract and the control.

Table 2 show the serum concentration of metabolites and enzymes in the control and experimental groups. There was significant alterations in the serum levels of analytes in rats administered arsenic chloride compared with the control. Treatment of rats with graded doses of Musa paradisiaca root extract reversed the anomaly close to that obtained in the control group.

Histological structure of the liver (Plate 1a-1d) and the kidney (Plate 2a-2d) indicates significant distortion in the architecture of the liver and kidney of rats administered arsenic chloride. Visible lesions, necrosis and cell discoloration were noticeable in the kidney and liver of arsenic treated rats. Photomicrograph of the tissues of rats treated with Musa paradisiaca root extract revealed essentially normal and well preserved liver and kidney cells with no deviation from that of the control.

\section{Discussion}

Administration of arsenic led to increase in size of the liver and kidney above the normal (Table 1) which could be as a result of inflammation caused by accumulation of fat or protein within the tissues [20]. Significant alteration in histological appearance characterized by necrosis and lesions of the liver and kidney were also observed in rats administered the arsenic. These effect were annulled in rats treated with Musa paradisiaca extract.

The observed significant reduction in protein contents and elevation of bilirubin and enzyme activities in the serum of rats administered arsenic (Table 2) indicates that the drug demonstrated mild toxicity in the liver. The decrease in total protein concentration could be due to liver diseases, protein malabsorption, decreased synthesis and nephrotic syndrome which led to protein loss through the kidney [21].

Table 1. Kidney and liver body weight index (\%) of rats administered aqueous extract of Musa paradisiaca root and arsenic chloride.

\begin{tabular}{lllll}
\hline & A & B & C & D \\
\hline Kidney & $2.32 \pm 0.32$ & $4.28 \pm 0.51 *$ & $2.56 \pm 0.48$ & $2.42 \pm 0.30$ \\
Liver & $4.51 \pm 0.44$ & $6.30 \pm 0.68 *$ & $4.65 \pm 0.87$ & $4.47 \pm 0.42$ \\
\hline
\end{tabular}

Values are Mean $\pm \mathrm{SD}, \mathrm{n}=6$. *Values are significantly different from the control group at $\mathrm{p}<0.05$.

Table 2. Kidney and liver function parameters in the serum of rats administered aqueous extract of Musa paradisiaca root and arsenic chloride.

\begin{tabular}{llll}
\hline & A & B & C \\
\hline Total Protein (g/dl) & $12.51 \pm 2.12$ & $7.34 \pm 1.20^{*}$ & $11.22 \pm 1.10$ \\
Albumin (g/dl) & $6.02 \pm 0.88$ & $3.45 \pm 0.65^{*}$ & $5.81 \pm 0.34$ \\
Globulin (g/dl) & $5.38 \pm 0.28$ & $3.12 \pm 0.54^{*}$ & $5.47 \pm 0.27$ \\
Total bilirubin (mg/dl) & $0.38 \pm 0.05$ & $1.02 \pm 0.08^{*}$ & $0.41 \pm 0.09$ \\
ALP (IU/L) & $107.62 \pm 7.22$ & $145.26 \pm 8.23^{*}$ & $118.77 \pm 5.36$ \\
ALT (IU/L) & $60.74 \pm 2.15$ & $87.58 \pm 4.37^{*}$ & $64.62 \pm 4.55$ \\
AST (IU/L) & $163.38 \pm 7.46$ & $201.72 \pm 9.88^{*}$ & $172.34 \pm 9.21$ \\
Urea (mg/dl) & $53.75 \pm 3.53$ & $78.66 \pm 5.26^{*}$ & $52.45 \pm 4.34$ \\
Creatinine (mg/dl) & $50.12 \pm 4.26$ & $66.26 \pm 5.88^{*}$ & 5.90 .38 \\
Uric acid (mg/dl) & $12.33 \pm 1.96$ & $22.17 \pm 2.36^{*}$ & $112.65 \pm 4.10$ \\
$\mathrm{BUN}^{*}(\mathrm{mg} / \mathrm{dl})$ & $25.10 \pm 2.97$ & $36.73 \pm 3.13^{*}$ & $13.40 \pm 2.12$ \\
$\mathrm{Na}^{+}(\mathrm{mmol} / \mathrm{L})$ & $101.52 \pm 8.38$ & $133.22 \pm 9.16^{*}$ & $26.83 \pm 3.74$ \\
$\mathrm{~K}^{+}(\mathrm{mmol} / \mathrm{L})$ & $16.08 \pm 2.43$ & $25.13 \pm 3.44^{*}$ & $108.47 \pm 8.88$ \\
$\mathrm{Cl}^{-}(\mathrm{mmol} / \mathrm{L})$ & $102.33 \pm 6.32$ & $166.55 \pm 5.77^{*}$ & $17.64 \pm 4.23$ \\
$\mathrm{HCO}_{3}^{-}(\mathrm{mmol} / \mathrm{L})$ & $18.75 \pm 1.65$ & $27.34 \pm 3.33^{*}$ & $110.84 \pm 6.00$ \\
\hline
\end{tabular}

Values are Mean $\pm \mathrm{SD}, \mathrm{n}=6$. ${ }^{*}$ Values are significantly different from the control group at $\mathrm{p}<0.05$.

The liver is the primary target organ for the metabolism of arsenicals where it is converted to methylated product [22]. Hepatocellular carcinoma have been frequently associated with environmental or medicinal exposure to arsenicals [23]. ALT and AST are pyridoxal phosphate-dependent enzymes involved in cellular nitrogen metabolism and liver gluconeogenesis. The enzymes are widely distributed in many tissues but is found in greatest abundance in the liver [24]. ALT and AST levels are routinely used as indicators of liver disease [25]. Rise in the level of aminotranferases is an indication of hepatocellular injury and the higher the rise, the greater the damage. Bilirubin is the major product of hemoglobin breakdown which rises in the serum when there is liver injury arising from infectious hepatitis, alcoholic hepatopathy, hepatic billiary hemolysis and neonatal jaundice [26].

The observed significant elevation of serum urea, creatinine, uric acid, blood urea nitrogen and electrolytes in the serum of rats administered arsenic chloride indicates disruption of kidney function [27]. The kidney plays essential roles in maintaining a number of vital body functions and alteration of normal kidney function by toxicants can results in disruption in blood waste elimination. For clinical purposes, alterations in wastes excretion, kidney weight and concentration of nitrogenous compounds in the blood are the principal indices for determining the effects of nephrotoxicants [28]. Compounds that cause renal vasoconstriction reduce the amount of blood that reaches the 
glomerulus and cause hypoperfusion, a reduction in the amount of blood filtered [29].

Results obtained in Table 1 and 2 as well as the histological sections indicate possible protective role of aqueous extract of Musa paradisiaca root on arsenic induced liver and kidney damage. Rats treated with the extract significantly reversed the insult caused by arsenic administration in the rats liver and the kidney.

The protective action of the herb might be due to pharmacological actions of the phytochemicals contain in the root extract [30]. The efficacy of any protective drug or herb on tissues depend on its capacity to either reduce the harmful effect or restoring the normal tissue physiology caused by a toxin. The observed restoration of kidney and liver functions by Musa paradisiaca root extract indicates its protective roles on the structural integrity of the tissues. Flavonoids and steroids present in the extract have strong antioxidant activity which help to protect tissues against oxidative attack thereby reducing the risk of liver and kidney damage. Plantain roots was also reported to contain apigenin, vitamin $\mathrm{A}, \mathrm{C}, \mathrm{E}$ and trace minerals such as magnesium, calcium, zinc and selenium all of which has antioxidant potentials [31].

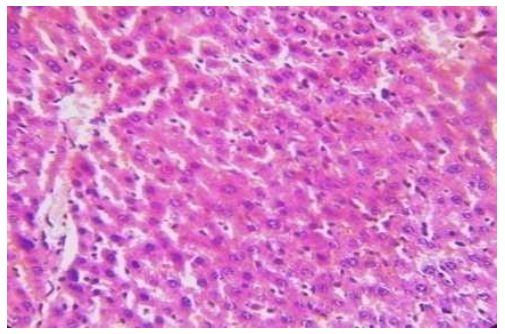

Plate 1a. Photomicrograph of liver section of normal control rat (haematoxylin \& eosin stained $X$ 400) showing essentially normal and well preserved cords of hepatocytes with no visible lesion.

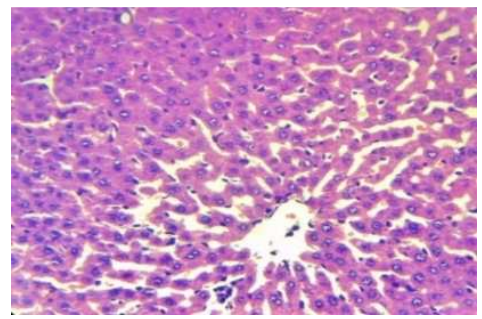

Plate 1b. Photomicrograph of liver section of rats administered arsenic chloride (haematoxylin \& eosin stained X 400) showing distorted hepatocyte. Mild hyperplasia and necrosis noticeable in the central vein. The cytoplasm appear vacuolated with signs of fatty degeneration.

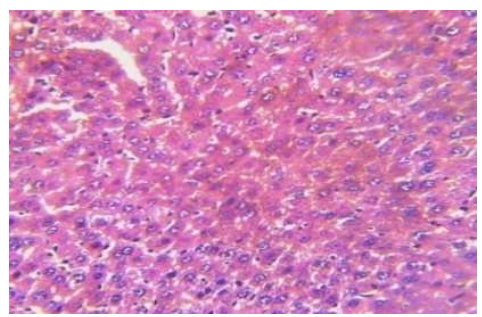

Plate 1c. Photomicrograph of liver section of rats administered arsenic chloride $+200 \mathrm{mg} / \mathrm{kg} \mathrm{bw} \mathrm{Musa} \mathrm{paradisiaca} \mathrm{roots} \mathrm{extract} \mathrm{(haematoxylin} \mathrm{\&}$ eosin stained $X 400)$ showing normal and well preserved hepatocytes with no significant histological alterations.

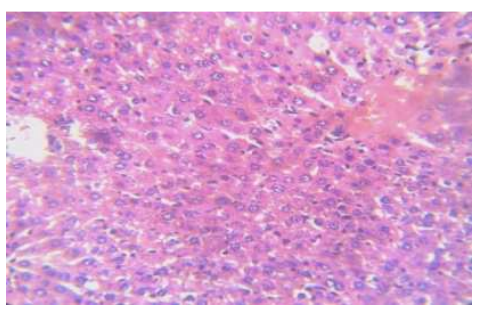

Plate 1d. Photomicrograph of liver section of rats administered arsenic chloride $+500 \mathrm{mg} / \mathrm{kg} \mathrm{bw} \mathrm{Musa} \mathrm{paradisiaca} \mathrm{roots} \mathrm{extract} \mathrm{(haematoxylin} \mathrm{\&}$ eosin stained $X 400$ ) showing normal and well preserved hepatocytes with no significant histological alterations

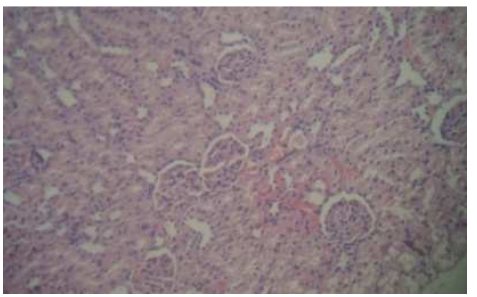

Plate 2a. Photomicrograph of kidney section of normal control rat (haematoxylin \& eosin stained X 400) showing well preserved and essentially normal kidney cell with no visible lesion.

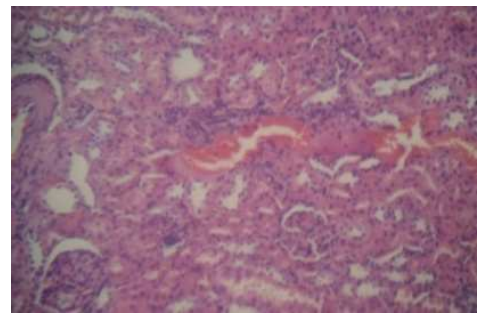

Plate 2b. Photomicrograph of kidney section of rats administered arsenic chloride (haematoxylin \& eosin stained X 400) showing severe perivascular cellular infiltration and mild congestion in many tubules. The tubules around the glomeruli appear degenerated and necrotic with some having protein casts in their lumen.

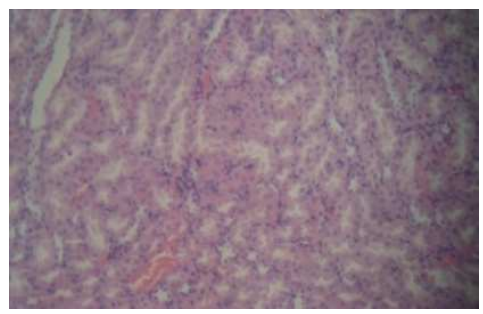

Plate 2c. Photomicrograph of kidney section of rats administered arsenic chloride $+200 \mathrm{mg} / \mathrm{kg} \mathrm{bw}$ Musa paradisiaca roots extract (haematoxylin \& eosin stained X 400) showing normal and well preserved kidney cell with no significant histological alterations.

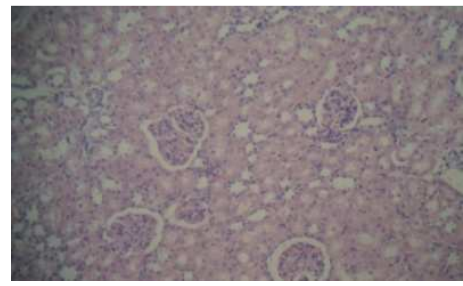

Plate 2d. Photomicrograph of kidney section of rats administered arsenic chloride $+500 \mathrm{mg} / \mathrm{kg} \mathrm{bw}$ Musa paradisiaca roots extract (haematoxylin \& eosin stained $X 400)$ showing normal and well preserved kidney cell with no significant histological alterations. 


\section{Conclusion}

We conclude from the present investigation that Musa paradisiaca root is a rich source of useful phytochemicals which can protect the liver and kidney against acute and repeated doses of arsenic chloride. This study is a further demonstration of the beneficial effect of Musa paradisiaca root as herbal remedy for the prevention and treatment of liver and kidney damage in folkmedicine.

\section{References}

[1] Wadei HM, Mai ML, Ahsan N, Gonwa TA. Hepatorenal syndrome: Pathophysiology and management. Clin. J. Am. Soc. Nephro. 2006; 1 (5):1066-1079.

[2] Cotran RS, Kumar N Fausho F, Nelson SL, Abbas AK. Robbins and Cotran pathological basis of disease. St Louis MO: Elsevier Saunders. 2005; pp: 878.

[3] Agency for Toxic Substances and Disease Registry-ASTDR. Toxicological profiles for arsenic. American publishing press. Atlanta. USA. 2005; pp:228.

[4] Ravenscroft P. Predicting the global distribution of arsenic pollution in ground water. Royal Geographic Soc. J. 2007; 25(2):45-59.

[5] Kharil I, Abedul H, Abdul F. Dose response relationship between arsenic exposure and the serum enzymes for liver function test in the individuals exposed to arsenic: Environ. Health J. 2011; 10 (64):102-115.

[6] Hughes MF. Accumulation and metabolism of arsenic in mice after repeated oral administration of arsenate. Toxicol. \& Applied Pharmacol. J. 2002; 191(3):202-210.

[7] Sharma SK, Gupta J. Plants having hepatoprotective activity. Phytochem. \& Pharmacol. J. 2002; 2:253-270.

[8] Capen RG. Food consumption table. East Asian Journal of Nutrition. 1990; 12(2):15-20.

[9] Ahlborn H, Henderson S, Davies N. No immediate pain relief for the pharmaceutical industry. Curriculum Opin. Drug discovery Development. 2005; 8(3):334-391.

[10] Harborne JB. Phytochemical methods. London Chapman and Hall Ltd. Pp. 49- 188. Moss DW, Rosalki SB (1996). Enzyme tests in diagnosis. Edward Arnold. London. 1973; pp. 68-77.

[11] Bancroft JD, Stevens A. Theory and Practice of Histological Techniques. Churchill Livingstone. 2nd ed. London. 1982; pp 95-108.

[12] Donninger LP, Hulson DH, Pickering BA. Modified biuret method of protein estimation. Biochem. J. 1972; 216:701-707.

[13] Doumas BT, Watson WA, Biggs HG. Albumin standards and the measurement of serum albumin with bromocresol green. Clin. Chim. 1971; Acta 31:87-96.
[14] Reitman S, Frankel S. Determination of glutamate-pyruvate transaminase (ALT) and Aspartate aminotransferase (AST). J. Clin. Pathol. 1957; 28:56.

[15] Wright PJ, Plummer DT, Leathwood PT. Enzyme in rat urine. Alkaline phosphatase. Enzymologia. 1972; 42:317-327.

[16] Jendrassik L, Groft P. Colorimetric methods of determination of bilirubin. Biochem. 1938; 2:81-82.

[17] Veniamin MP, Vakirtzi-Lemonia C. Chemical bases of the carbamidodiacetyl micro method for estimation of urea, citruline and carbamyl derivatives. Clin. Chem. 1970; 16:3-6.

[18] Fischbach FT, Dunning MB. Manual of laboratory and diagnostic test, $8^{\text {th }}$ edition, Philadelphia: Lippincott Williams and Wilkins. 2009; pp: 250.

[19] Tietz NW. Clinical guide to laboratory test ( $1^{\text {st }}$ edition). Saunders Publication, London-UK. 1983; pp 135:148.

[20] Friedman PBC. Effect of diseases on clinical laboratory test. Am. Soc. Clin. Chem. J. 1980; 5(2):122-125.

[21] Moss DW, Rosalki SBR. Enzyme tests in Diagnosis. $2^{\text {nd }}$ edition. Edward Arnold. London. 1996; pp 201-213.

[22] Tseng CH. Urinary arsenic methylation in animals. Journal of Environ. Sci. Health Care. 2007; 25(1):1-22.

[23] Tseng CH, Chong CK, Tseng CP. Long-term arsenic exposure and ischemic heart disease in arseniasis-hyperendemic villages in Taiwan. Toxicol. Lett. 2003; 137:1-2.

[24] Guyton AC, Hall JE. A textbook of medical physiology $10^{\text {th }}$ Edition., W.B. Saunders Co., Philadelphia, 2000; pp 382-401.

[25] Schmidt E, Schmidt FW. Enzyme diagnosis in diseases of the liver and biliary system. Adv. Clin. Enzymol J. 1979; 1:239-242.

[26] Sanjiv C. The liver book: a complementary guide to diagnosis, treatment and recovery ( $2^{\text {nd }}$ edition). Atria Jimcafe Company. 2002; pp 86.

[27] Cameron JS, Greger R. Renal function and testing of function. Oxford Textbook Clin. Nephrol. 1998; pp 36-39.

[28] Wang W, Srivastava S. "Serological markers" In Breslow, Lester Encyclopedia of Public Health. NY. Macmillan, USA. 2002; pp 1088-1090.

[29] Oyewole OI, Oladipupo OT, Atoyebi BV. Assessment of renal and hepatic functions in rats administered methanolic leaf extract of Jatropha tanjorensis. Annals of Biol. Research. 2012; 3 (2): 837-841.

[30] Ibegbu AO, Okonji WO, Umana DJ, Musa SA. Anti-inflammatory effects of the aqueous extract of plantain roots. Brit. J. Pharmacol. \& Toxicol. 2012; 3 (2): 70-75.

[31] Lewis DL, Shaw GP. A natural flavonoid present in unripe plantain pulp (Musa sapientum L.V. paradisiaca).Protects the gastric mucosa from aspirin-induced erosions. J. Ethnopharmacol. 2001; 65:283-288. 